\title{
An Empirial Study on the Effectiveness of Entrepreneurship Education in Developing Entrepreneurial Intention Among Malaysian University Students
}

\author{
Parimala Rengiah, Ilham Sentosa \\ School of Business, University Kuala Lumpur, Kuala Lumpur, Malaysia \\ Email address: \\ parim53@hotmail.com (P. Rengiah),ilham@unikl.edu.my (I. Sentosa)
}

\section{To cite this article:}

Parimala Rengiah, Ilham Sentosa. An Empirial Study on the Effectiveness of Entrepreneurship Education in Developing Entrepreneurial Intention Among Malaysian University Students. Education Journal. Vol. 5, No. 4, 2016, pp. 53-61. doi: 10.11648/j.edu.20160504.13

Received: May 7, 2016; Accepted: May 24, 2016; Published: June 30, 2016

\begin{abstract}
Entrepreneurship education has been the focus in the Malaysian universities and entrepreneurial intentions have been proven as the primary predictors for future entrepreneurial behaviour among the students. Structural equation modelling is proposed as the methodology for the study as 'entrepreneurial intentions' is a 'latent' or 'unobservable' behaviour. A hypothetical model was developed for the study. Data was collected from 396 university students and analysed using structural equation modelling through AMOS 22.0. The model was tested through a two-stage SEM. The first stage was tested using a confirmatory factor analysis to evaluate constructs of validity and all CFA on constructs were tested for goodness fit of the structural model. The data was analysed with the conclusion and findings together with the implications of theory and practice. The paper discusses the recommendations for the study with regard to how entrepreneurship curricula and teaching methodologies should be improved and the roles of Malaysian universities in promoting entrepreneurship. Methods of how students' attitudes could be changed towards entrepreneurship, the roles of the government, SMEs, financial institutions and the parents of students towards a entrepreneurial society have been discussed. The limitations for the study and suggestions for further research have been proposed.
\end{abstract}

Keywords: Entrepreneurship Education, Teaching Methodologies, Universities Roles, Roles of the Government, Stakeholders, Entrepreneurial Intentions

\section{Introduction}

Malaysia is a developing country and has a high rate of unemployment among the young graduates emerging from the universities. The majority of graduates emerging from the Malaysian universities prefer job employment rather than self-employment. Other contributing factors are lecturers' lack of knowledge and entrepreneurial skills, lack of experience, training and mastery of teaching methods [1]. Entrepreneurship education has been growing in importance in Malaysia and the Malaysian government is taking great efforts in transforming into a knowledge-based economy, to nurture entrepreneurship in all ways [2]. The higher educational institutions both public and private in Malaysia started offering entrepreneurship education and it has been included as one of the subjects in the curricula of business and other courses for students $[3,4,5]$. A hypothesised model was developed for the study using Structural Equation Modelling (SEM) approach to examine the entrepreneurial intentions of the Malaysian university students through entrepreneurship education [6]. The exogenous variables in the hypothetical model was entrepreneurship education, its components being entrepreneurship curricula, teaching methodologies and university support to test the endogenous variable of entrepreneurial intentions through the mediating variables of attitudes and stakeholder support systems. The hypothesised model developed for the study was tested for goodness-of-fit indices of direct and indirect effect of the exogenous variables with the endogenous variable through the mediating variables. Initially a generated model was developed through the two-stage process of confirmatory factor analysis, and then a re-specified model emerged [7]. As a rule of thumb in SEM, the variables of attitude was renamed as 'attitude towards goals' and stakeholder support 
system was renamed 'family roles'. The analysis of structural path in the second re-specified model embarked on testing the original model of entrepreneurial intentions. A competing model exhibited a good fit indicating the robustness of the study. A brief analysis of the data analysis with the conclusion and findings were discussed followed by recommendations for the study.

Recommendations were suggested in the paper as to how improvements could be made towards the entrepreneurship curricula and teaching methodologies in universities and roles of the universities in realising the importance of entrepreneurship and cultivating it in the minds of the students. The recommendations also included how to improve the attitudes of students in the universities, stakeholders' roles such as the government, financial institutions and the parents of the students towards entrepreneurial intentions. Limitations to the study have been discussed and suggestions for further research have been proposed.

\section{Literature Review}

The literature review probes into concepts and theories of entrepreneurship education and entrepreneurial intentions. A theoretical framework is proposed developing a hypothetical model of entrepreneurship education as the independent variables to test the dependent variable of entrepreneurial intentions through the mediating factors of attitudes and stakeholder support system as mediating variables [6].

i) Entrepreneurship curricula

Entrepreneurship curricula are important factors in promoting entrepreneurship education in universities and higher educational institutions through their programs, learning and training models. The entrepreneurship programmes promote and enhance skills acquisition, ease the spirit of creativity, self-reliance and self-independence $[8,9$, 10, 11, 12, 13, 14].

Hy1: Entrepreneurship curricula are positively related to entrepreneurial intentions.

ii) Teaching methodologies

Research suggested that though individuals are born with entrepreneurship characteristics, their levels of entrepreneurial activities will increase if the entry level entrepreneurial skills are taught. It is not about teaching how to run a business, but about encouraging creative thinking and promoting a strong sense of self-worth and accountability. Many of the higher educational institutions are teaching entrepreneurship programs to increase entrepreneurial skills among university students $[15,16,17,18,19,20]$.

Hy2: Teaching methodology is positively related to entrepreneurial intentions.

iii) University roles

The universities play important roles in developing students' entrepreneurial inclinations. Their entrepreneurship programs and teaching environment are seen as the most influential factors in developing entrepreneurial intentions among the university students [21, 22, 23, 24, 25].

Hy3: University role is positively related to entrepreneurial intentions.

\section{iv) Attitudes}

Attitudes are seen as an important variable in the prediction of starting businesses or enterprises among university students [26]. The attitudes in this study are classified as attitudes towards money, attitudes towards change and attitude towards entrepreneurship [27, 28, 29, 30, 31, 32, 33, 34].

Hy4: Attitude is positively related to entrepreneurial intentions.

v) Stakeholder support systems

Stakeholder support systems that comprises of the government support, financial and parents' support influences the students' intentions towards entrepreneurial activities [35, 36, 37, 38, 39, 40, 41, 42, 43].

Hy5: Stakeholder support system is positively related to entrepreneurial intention.

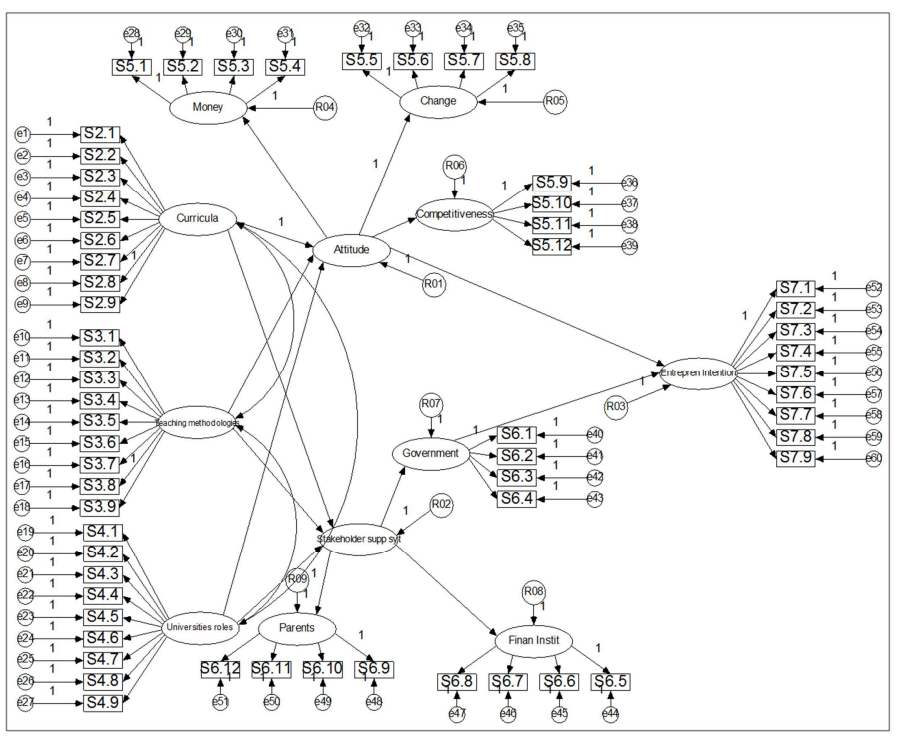

Source: Developed for the Research through AMOS 22.0

Fig. 1. Proposed Hypothesised Model. 


\section{Methodology}

The methodology proposed in this study is descriptive research analysed though SPSS version 22.0 and develop a structural model through Structural Equation Modeling (SEM). The research consists of theoretical constructs that cannot be observed. The endogenous variable in the study is 'entrepreneurial intentions' and it is a 'latent' or 'unobservable' variable. The latent variables are not observed directly and cannot be measured directly. Hence, the unobservable variable is linked to one that is observable so that the measurement is possible [7]. The endogenous variable comprises of entrepreneurship education, its components being entrepreneurship curricula, teaching methodologies and university roles to test the endogenous variable of entrepreneurial intentions through the mediating variables of attitudes and stakeholder support systems. The hypothesized model developed for the study has to be tested through AMOS version 22.0 [44]. Refer Fig. 1.

\section{Data Analysis and Findings}

A total of 396 cases were analysed for the study using structural equation modeling. Statistical validity tests and analysis were conducted such as reliability test and composite reliability tests, validity tests using confirmatory factor analysis (CFA) for construct validity, descriptive analysis, correlation and structural equation modelling analysis (SEM) using AMOS 22.0.

Structural Equation Modelling technique was used in the analysis of data through confirmatory factor analysis to test the hypothesised model developed for the study. The model is tested through factor loading of confirmatory factory analysis on every construct and measurement models for goodness of fit indices, such as CMIN/df ratio $(<2)$, p value $(>0.05)$, goodness of fit index (GFI $>0.90)$, and root mean square error of approximation (RMSEA) values of less than $<0.08$. Refer Table 1 .

Table 1. Summary of Goodness-of-fit Index of Variables.

\begin{tabular}{|c|c|c|c|c|c|c|c|}
\hline \multirow[t]{2}{*}{ Variable } & \multirow[t]{2}{*}{ Dimension } & \multicolumn{5}{|c|}{ GoodnessofFit } & \multirow[b]{2}{*}{ RMSEA } \\
\hline & & $\mathbf{X}^{2}$ & DF & Ratio & $\mathbf{P}$ & GFI & \\
\hline \multirow{5}{*}{$\begin{array}{l}\text { Entrepreneurial } \\
\text { Intentions } \\
\text { (ENTINT) }\end{array}$} & Curricula & 13.145 & 8 & 1.643 & 0.107 & 0.989 & 0.040 \\
\hline & Teachingmethodologies & 9.533 & 5 & 1.907 & 0.09 & 0.991 & 0.048 \\
\hline & Universitiesroles & 10.045 & 8 & 1.256 & 0.262 & 0.992 & 0.025 \\
\hline & Attitude & 11.119 & 11 & 1.011 & 0.433 & 0.992 & 0.005 \\
\hline & Stakeholdersupportsystems & 27.85 & 24 & 1.16 & 0.266 & 0.985 & 0.020 \\
\hline
\end{tabular}

Source: AMOS 22.0

In SEM, the CFA models have no causal paths connecting the latent variables (independent and dependent variables). The latent variables may be allowed to correlate (oblique factors) or be constrained to ' 0 ' covariance (orthogonal factors). The CFA analysis in SEM focuses on analysis of the error terms of the indicator variables. The standard CFA model has each indicator specified to loan only on one factor, measurement error terms are specified to be uncorrelated with each other, and all factors are allowed to correlate with each other. Onefactor standard models are identified if the factor has three or more indicators (Hair et al. 2014). Multi-factor standard models are identified if each factor has two or more indicators. In CFA, the chi-squares are significant in the presence of a large sample size but based on the Maximum Likelihood Indicators (MLI) of factor loadings, goodness-of-fit indexes and normalised residuals. All model fit indices showed a good fit between the model and the raw data. CFA was conducted on the six dimensions of entrepreneurial curricula, teaching methodologies, university roles, attitudes, stakeholder support systems and entrepreneurial intentions. CFA $1^{\text {st }}$ order analysis was conducted on the three independent variables of entrepreneurship curricula, teaching methodologies, university roles and independent variable of entrepreneurial intentions. CFA $2^{\text {nd }}$ order analysis was conducted on attitudes and stakeholder support systems. The CFA $1^{\text {st }}$ order and CFA $2^{\text {nd }}$ order analysis emerged with a generated model. The generated model did not have a good fit of indices, so it was tested again, a re-specified model was generated. The re-specified model confirmed the final model of the hypothesised model, showing the significant of the goodness of fit indexes that confirmed the significant loadings of the measurements, the low level of common and unique error, and the interaction among predictors on endogenous variables.

The structural model output explained a substantial part of the variance in all the endogenous variables. In addition the model also showed the standardised path coefficients and its significant levels on causal paths. The re-specified model confirmed the constructs of curriculum teaching methodology, university role, attitude, stakeholder support system and entrepreneurial intention in the model. Factor analysis and hypotheses were tested in the same analysis. The SEM techniques used provide full information about the extent to which the research model is supported by the data with the goodness of fit statistics of SEM.

As a rule of thumb of structural equation modelling (SEM), the re-specified model was again revised. The mediating variables of attitude and stakeholder support system has only one component each, attitudes was renamed as 'attitude towards goals' and stakeholder support systems was renamed as 'family roles'. The second re-specified model is constructed with the remaining items in the variables and the new components and tested for the goodness-of-fit of the model. The second re-specified model was further tested and a competing model emerged. The competing structural model exhibits a good fit indicating the robustness in the study Refer Fig. 2. 


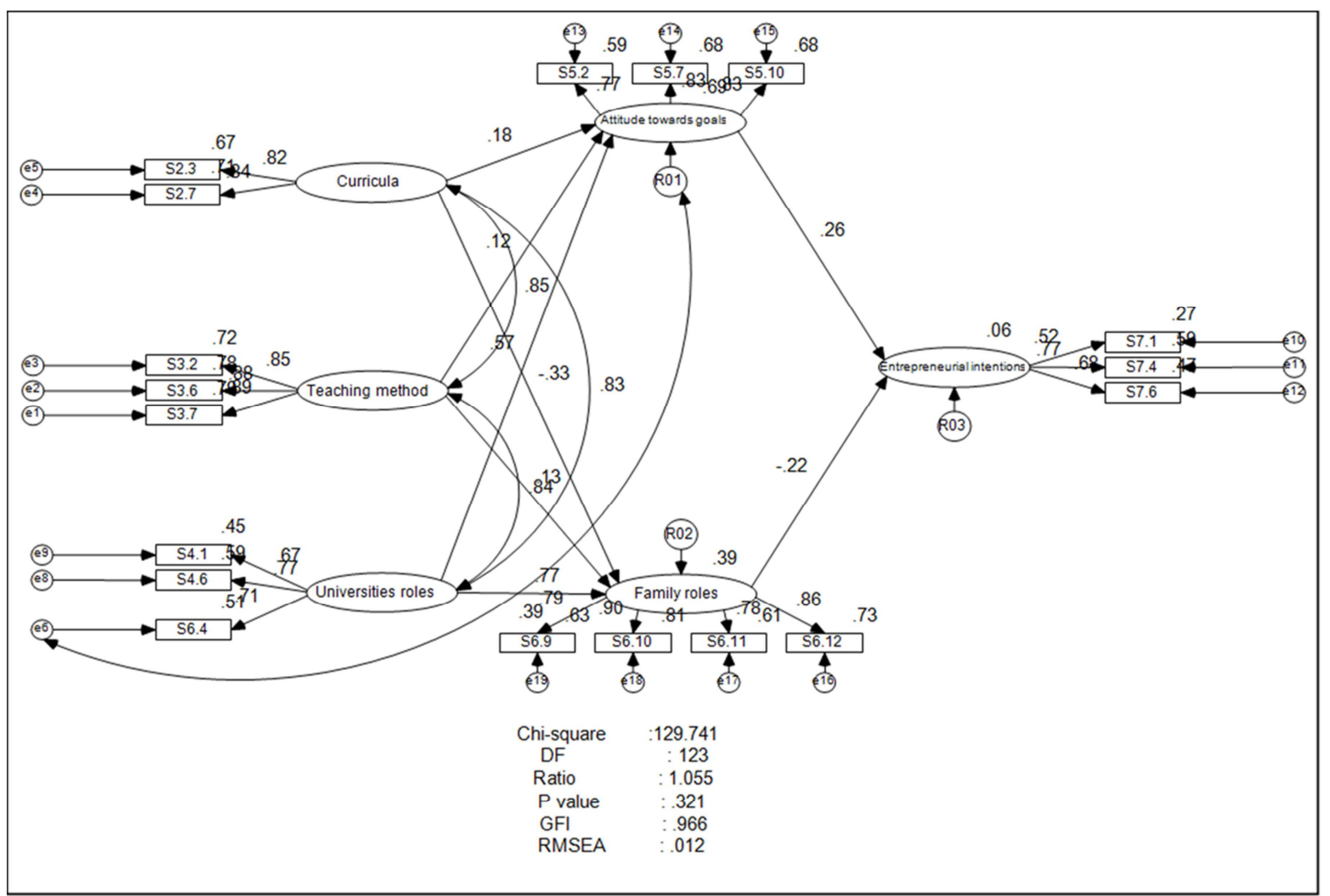

Source: AMOS 22.0

Fig. 2. Competing Final Model.

The direct and indirect effect in the relationship between the education variables (curricula, teaching methodologies and universities roles), attitude towards goals, family roles and entrepreneurial intentions were measured by the application of path analysis technique. The factor loadings of the nineteen items in the study have been analysed with the standard regression weights to calculate the square multiple correlations. The five hypotheses developed for the study have been tested. The exogenous variables of curricula, teaching methodologies and university roles have been tested through the mediating effects of attitude towards goals and family roles and the results showed that three of the hypotheses $\mathrm{H} 3, \mathrm{H} 4$ and $\mathrm{H} 5$ are positively significant, whereas $\mathrm{H} 1$ is partially significant and $\mathrm{H} 2$ as negatively significant. The square multiple correlations the (adjusted $\mathrm{R}^{2}$ ) of each dimension of the entrepreneurship education variable to the mediating variables shows the results as attitude towards goals $(\beta=0.694)$, family roles $(\beta=0.39)$ and entrepreneurial intentions $(\beta=0.059)$. The mediating variable has contributed $69.4 \%$ variance of attitude towards goals indicating that it has a medium level of contribution to the structural model. The mediating variable has contributed $39 \%$ variance of family roles indicating that family roles have a medium level of contribution to the structural model. The endogenous variable of entrepreneurial intentions has contributed $5.95 \%$ variance indicating that entrepreneurial intentions have a low level of contribution to the structural model and that it is not significant to the study. Refer Table 2.
Table 2. Squared Multiple Correlations estimates.

\begin{tabular}{lll}
\hline Squared Multiple Correlations & Estimates & Percentage \\
\hline Attitude towards goals & 0.694 & $69.4 \%$ \\
Family roles & 0.390 & $39 \%$ \\
Entrepreneurial Intentions & 0.059 & $5.9 \%$ \\
\hline
\end{tabular}

Source: AMOS 22.0

\subsection{Discussions}

Based on the research findings, following items are suggested for practical implementation by the Malaysian universities and the stakeholders to improve entrepreneurship education systems in the country.

i) Entrepreneurship programs

'Entrepreneurship' as a compulsory subject to all university students in the country and it is timely in providing basic entrepreneurial knowledge and skills. Specific entrepreneurial courses such as business planning, entrepreneurial finance, creativity and innovation, marketing, and field projects should be included in the business programs. The courses should involve innovative cocurricular programs, outside the classrooms, focus on students 'live' entrepreneurial programs as a comprehensive venture accelerator of student run entrepreneurial organisations and forums and entrepreneurial eco-systems as in the educational institutions in the Western countries. 
Entrepreneurship curricula should consider the features to start up business ventures and include critical thinking, experiential learning methods, visits to industries and business areas, inviting guest speakers who are successful entrepreneurs. In collaboration with partnership programs or consulting relationships from world-class institutes such as Babson College, Massachusetts Institute of Technology, Stanford University, which has a leading brand in entrepreneurship education, will be beneficial to the Malaysian universities.

ii) Teaching methods and Pedagogies

The teaching of entrepreneurship courses should not be undertaken in mere classroom settings but rather as a process which involves start-up businesses, entrepreneurial activities, design-based learning, and reflective practices. Starting businesses as part of coursework by the students in the first year of their courses, is a way of encouraging them for the entrepreneurial process as the focus is on entrepreneurship recognition, resource planning, team development, holistic thinking and value creation. Incorporating real-world practice of business creation into the entrepreneurship courses, the students develop a level of insight and confidence from practicing methods for navigating unknown territories, experience success and failure, gain knowledge and importance of leadership, managing human resources, decision-making and effective communication skills. Including business plan competitions and experimental games in the entrepreneurial curricula make it more interesting. The purpose of this method of teaching is to compact business creation process in order to map the creation of organisational culture through the way the student as an entrepreneur uses his or her time and money in relation to the business, employees and the community.

iii) Role of the Malaysian Universities

The Malaysian universities need to re-evaluate the curricula if they were to promote entrepreneurship in an effective way by creating an entrepreneurially friendly environment to instill entrepreneurial behaviour among the students. It is essential to promote an entrepreneurial environment through the introduction of entrepreneurial activities and entrepreneurial clubs. Through active participation in the entrepreneurial activities, the students not only get exposed to practical experiences of entrepreneurship but to real-business world situations. The universities should cultivate an enterprise culture across campuses to influence the students' decisions for business creations and by presenting a positive image of entrepreneurship as a career option. They should cultivate a strategic direction towards entrepreneurship to achieve the national objectives. This could be achieved through extended internship programs, entrepreneurial trainings, technology spin-off activities, entrepreneurial clubs, partnership with SMEs and international universities that are entrepreneurially inclined.

iv) Attitude of Students towards Entrepreneurship

Students enrolled for entrepreneurship courses require a different learning approach from the others. Entrepreneurship students are considered as proactive, creative and innovative learners and should possess exceptional personality traits and skills attributed to entrepreneurship. Considering this, the Malaysian universities should design a curriculum that would suit to entrepreneurial learning purpose and change their conventional teaching methods to more on experiential learning. A 'student-centred' learning approach instead of a 'teacher-centred' learning approach is more suited to entrepreneurship students. This approach is based on an individual's creativity, analytical and working skills and even with the intent of changing of behaviour towards entrepreneurship. Preparing them for business plans and starting business projects would increase their attitude towards entrepreneurship.

\section{v) Role of the Government}

The main objective of the government through its national policies is to restructure the Malaysian society, mainly the Bumiputras to own $30 \%$ of the corporate wealth of the country, to achieve rapid growth and industrialisation. The government had planned various activities and programmes in the institutions of higher learning in order to produce 150,000 entrepreneurs among the graduates (MECD statistics 2008). Through the provision of financial aid to help graduates venture into new businesses (SME Bank Annual Report 2006), the focus of the government was on Malay graduates to involve more in entrepreneurship, but still todate the government has not achieved this objective. The government should play a more active role in the development of entrepreneurship by providing more assistance to the SMEs through funds and business loans, implementation of acculturation programs, increase entrepreneurial training, and set up more training centres for graduates to enhance their skills and technology. In addition to this, the government should create and encourage more business opportunities to ensure more Bumiputras venture into entrepreneurship.

\section{vi) Small Medium Enterprises}

There are many challenges faced by SMEs in Malaysia, which are linked to the ability to move up the value chain and to adopt to new ways of management. Competing with large markets in Asia is tough as they must have quality, cost, reliability and speedy delivery in the global market. The focus should not be only in the domestic market, but towards a niche in the world global supply chain. Most of the global corporations are relying increasingly on internet based business-to- business. The SME owners and managers in Malaysia have limited knowledge of acquisition and shortage of skills for the business environment, therefore the SME agencies should equip them with more training on internet based businesses.

vii) Role of Financial institutions

The financial institutions set up in Malaysia for entrepreneurial development are the SME Bank, Credit Guarantee Corporation, Commercial banks, Venture capital companies, Central Bank, Ministries and agencies. Their main role is the disbursement of loans to approved SMEs and entrepreneurs and providing advisory services. There have 
been complaints that too much time is spent on processing the loan applications, to disburse the approved loans and have complicated procedures. These issues could be addressed by having a simple loan application without complicated procedures and a one-stop centre that would consolidate the government financing where all the parties could obtain standardised information on financing schemes.

viii) Parents and Extended Family Members

Individuals with close family members who own businesses are likely to become future entrepreneurs compared to those who do not. The advantage of individuals with parents or close family members owning businesses is that they are able to provide access to relevant information, markets, financial support and other necessary resources for business information. Entrepreneurial parents tend to provide inspiration, encouragement and support for their children since young to get involved in entrepreneurial activities. The encouragement given by parents, the continuous involvement in family business, enhancing the students' confidence in business through close guidance and monitoring will motivate the students to be involved in business. Parents act as role models not only in their leadership style but also in recognising entrepreneurial opportunities and being adventurous in trying out new business ideas.

ix) Other Recommendations

\section{Information Technology related businesses}

The global situation is enormously linked to information technology where businesses could be set up in homes and virtual offices. Considering this, the university students should be more IT savvy and have adequate knowledge of how businesses could be set up through the web-sites and internet.

\section{Training}

Other than the normal entrepreneurship curriculum, students should be given adequate training in entrepreneurial activities. The training program courses should be more practical-orientated and could run for four to six months. The courses should emphasise the pre-start and start-up stages of business creation as they are the most challenging stages for embarking on a business venture.

\section{Establishing links with business organisations}

The universities should have strong links with industries or multinational companies where they could send the students for internship programs or gain practical experiences in entrepreneurship. The internship programmes should be made compulsory for the university students as it is crucial for them to learn and apply the practical knowledge during their working time to prepare them for the business ventures.

\section{Business and Advisory Centres}

Many of the university students have the knowledge and skills but lack experience in the procedures of setting up businesses and how to run them. The universities could set up business and advisory centres in campuses to provide information on funding, start-up processes, product development, business plans, business premises and advice on legal procedures and where experienced staff act as mentors.

\subsection{Limitations of the Study}

The present study was restricted to only four entrepreneurship focused universities in Malaysia. There are other public and private universities that are also focused in entrepreneurship studies but not included in the study. Thus the study is limited to only some entrepreneurship-focused universities in Malaysia. The study examined the relationships between entrepreneurship education and entrepreneurial intentions and the mediating effects of attitude and stakeholder support systems in the relationships. The study is limited to the relationship between these variables only.

The methodology employed was the survey method using a set of questionnaires. Through this method the research attempts to predict entrepreneurial intentions of students in the Malaysian universities by questioning what they will do or what assumptions they would make about their likely behaviour based on how they have answered the questionnaires. Thus the limitation of the interpretation of the results is limited to the survey research method only.

The study utilises the stratified sampling techniques to determine the sampling size. Due to the sampling technique employed, the finding is limited to the sampling technique. The sample population included were not only the Malaysian university students. The sample of the population might have underrepresented as among them were foreign students studying in the universities. The finding is limited to the sample population. The study used 7-point Likert-type scale for respondents to indicate their degree of agreement with the statements on entrepreneurship education, attitudes, stakeholder support systems and entrepreneurial intentions. Thus, the content of the study is limited to the understanding that all respondents understand the statements in the questionnaires used for the study. In the present study, the instrument measured perceptions. It has been assumed that the respondents were telling the truth about their perceptions on entrepreneurship education provided by the Malaysian universities.

The present study used a cross-sectional study and not a longitudinal study to view entrepreneurial intentions among students. The finding of the research is limited to a crosssectional study. Factors like students' intentions are likely to change over time and could be influenced by other factors not covered in the research study. The constructs were measured with multi-items scales and may result in loss in scale validity and reliability.

\subsection{Suggestions of Further Research}

Considering the limitations of the present study, there are promising avenues for future research. It is proposed that further research should consider the following areas or aspects: The present study was conducted to investigate the mediating effect of attitude and stakeholder support systems in the relationship between entrepreneurship education and entrepreneurial intentions in four entrepreneurship-focused universities in Malaysia. Future research may be conducted 
in other Malaysian universities by modifying some of the dimensions found in the present study. Such studies could enrich knowledge on variables in the evaluation of entrepreneurial intentions within the entrepreneurship education settings.

The present study employed the survey method that used a set of questionnaires as measurement scale. Future studies could consider the use of other tools such as interviews, and focus groups to collect the required data for measuring entrepreneurship education and entrepreneurial intentions. The study employed was the survey method using a set of questionnaire. Through this method the research attempts to predict entrepreneurial intentions by asking what they will do and making assumptions about their behaviour based on how they have answered the questionnaire. The present study emphasises on what the respondents say and they will do or what the researcher assumes they will do. Future research should emphasise on what the respondents do by using the direct interaction research method or interview methods. The researcher could have direct interaction with the respondents. Through this method there will be a twoway communication where any unclear questions or doubts could be answered.

The present study is limited to only business and information technology students. Future research could be conducted with non-business students, in the fields of engineering, hospitality, legal, architecture, accounting and medical fields. The current research focuses on crosssectional study, and does not examine the entrepreneurial intentions on a time-line basis. The time frame between the students' graduation and their involvement in entrepreneurial activities is not taken into account. Further research could be conducted to examine the entrepreneurial intentions on a longitudinal study to evaluate the number of university students who have turned entrepreneurs in the country. This assertion needs to be validated by further research that includes independent replications. The mediator model could be expanded and validated beyond the attitude and stakeholder support systems. Further research exploring the relationship between entrepreneurship education and entrepreneurial intentions is necessary and appropriate.

\section{Conclusions and Recommendations}

The present study discusses the recommendations for the study of effectiveness of entrepreneurship education in developing entrepreneurial intentions among Malaysian university students. A theoretical framework with a hypothetical model was developed for the study. The independent variable of entrepreneurship education, its components of entrepreneurship curricula, teaching methodologies, university roles were tested with the dependent variable of entrepreneurial intentions, through the mediating factors of attitudes and stakeholder support systems. A brief description of the literature review and methodology using structural equation modelling was discussed. The data was analysed through structural equation modelling techniques through AMOS 22.0. As a rule of thumb in SEM, two new variables emerged as attitude towards goals and family roles that were contributions to the study. The findings contributed to some of the theories related to both the mediating variables attitude towards goals, family roles and entrepreneurial intentions.

Recommendations were proposed as to how the curricula and the teaching methodologies could be revamped to boost the entrepreneurial intentions of the students. The roles of policy makers such as the universities, the government, SMEs, financial institutions and the parents and extended family members as to their contributions towards entrepreneurial intentions have been discussed. Limitations of the present study were presented and suggestions for further research have been proposed, concluding that exploring the relationship between entrepreneurship education and entrepreneurial intentions is necessary and appropriate.

\section{References}

[1] Hamdul Hadi, N. M. \& Fakhrul A. Z. (2015). A Conceptual Model for Entrepreneurial Quality among Students of Higher Education Institutions (HEI) in Malaysia. International Journal of Academic Research in Business and Social Sciences, 5 (3), 433-443.

[2] Cheng, M.Y, Chan, W.S., Mahmood, A. (2009). The effectiveness of entrepreneurship education In Malaysia. Education \& Training, 51 (7), 555-566.

[3] Norhatta Mohd., Siti Mistima Maat \& Salwah Che Mat. (2015). A Study on Entrepreneurial Intention among Engineering Technology Students. Mediterranean Journal of Social Science, 6 (4), 348-355.

[4] Yusof, M. H., Zainol, F. A., \& Ibrahim, M. D. (2014). Entrepreneurship Education in Malaysia's Public Institutions of Higher Learning-A Review of the Current Practices. International Education Studies, 8 (1), 18-28.

[5] Fong, C. O. (2005). The official opening Malaysia Career and Training Fair, viewed April 10 2006, www.mohr.gov.my/mygoveg/makluman/spm447.htm.

[6] Rengiah, P. \& Sentosa, I. (2014). A Conceptual Development of Entrepreneurship Education and Entrepreneurial Intentions among Malaysian University Students. Journal of Business and Management, 16 (11), 68-74.

[7] Byrne, B. M. (2013). Structural Equation Modelling, Basic Concepts, Applications, and Programming, published by Lawrence Erlbaum Associates, Inc.

[8] Diaz-Garcia, C, Sảez-Marinez, F \& Jimẻnez-Moreno, J. (2015). Assessing the impact of the entrepreneurs' education programme on participants' entrepreneurial intentions. RUSC, Universities \& Knowledge Society Journal, 12(3), 17-31.

[9] Oyugi, J. L. (2004). Effectiveness of the methods of teaching entrepreneurship courses to developing self-efficacy and intention among university students in Uganda', International Journal of Social Sciences and Entrepreneurship, 1(11), 2014, 491-513. 
[10] Neneh, B. N. (2014). An assessment of entrepreneurial intention among university students in Cameroon. Mediterranean Journal of Social Science. 5 (20), 542-552.

[11] Sheta, A. (2012) Developing an Entrepreneurship Curriculum in Egypt: The Road Ahead. Journal of Higher Education Theory and Practice, 12(4), 2012, 51-65.

[12] Roudaki, J. (2009). University Students Perceptions on Entrepreneurship: Commerce Students Attitudes at Lincoln University. Journal of Accounting - Business \& Management, $16(2), 36-53$.

[13] Solomon, G. T. (2007). An examination of entrepreneurship education in the United States. Journal of Small Business and Enterprise Development, 14, (2), 168-82.

[14] Menzies, T. \& Tatroff, H. (2006). The propensity of male vs. female students to take courses and degree concentrations in entrepreneurship. Journal of Small Business and Entrepreneurship, 19 (2), 203-23.

[15] Glen, R, Sucin, C, Christopher Baugher, C, \& Anson, R. (2015). Teaching design thinking in business school. The International Journal of Management Education, 13(2), 182192.

[16] Fatoki, O. (2014). The Entrepreneurial Intention of Undergraduate Student in South Africa. The influence of Entrepreneurial Education and Previous Work Experience. Mediterranean Journal of Social Science. 5 (7), 294-299.

[17] Laguador, J. M. (2013). A Correlation Study of Personal Entrepreneurial Competency and the Academic Performance in Operations Management of Business Administration Students. International Journal of Academic Research in Business and Social Sciences, 3 (5), 61-70.

[18] Zahra, A., Manasoreh, K.. F. \& Narges, I. (2012). A Study of Teaching Methods in Entrepreneurship Education for Graduate Students. Higher Education Studies, 2(1), University of Tehran.

[19] Fayolle, A., \& Gailly, B. (2008). From Crafts to Science. Journal of European Industrial Training, vol. 32, no. 7, pp 569-593.

[20] Krueger, Jr. N. F. (2007). What lies beneath? The experiential essence of entrepreneurial thinking', Entrepreneurship Theory and Practice, 31(1), 123-138.

[21] Nasira', A. Yeng Keat, O \& Awais Bhatti, M. (2015). Influence of Perceived University Support, Perceived effective entrepreneurial education, Perceived creativity disposition, Entrepreneurial passion for inventing and founding on entrepreneurial intention. Mediterranean Journal of Social Science, 6 (3), 88-95.

[22] Zhang, Y., Duysters, G. \& Cloodt, M. (2014). The role of entrepreneurship education as a predictor of university Students' entrepreneurial intention, 10(3), 623-641.

[23] Linan, F., Rodriguez-Cohard, J. C. \& Rueda-Cantuche, J. M. (2011). Factors affecting entrepreneurial intention levels: a role for education. International Entrepreneurship and Management Journal, 7 (2), 195- 218.

[24] Yar Hamidi, D., Wennberg, K. \& Berglund, H. (2008). Creativity in entrepreneurship education. Journal of Small Business and Enterprise Development, 15 (2), 304-320.

[25] Nurmi, P., \& Paasio, K. (2007). Entrepreneurship in Finnish Universities. Education + Training, 49 (1), 56-65.
[26] Fayolle, A. \& Gailly, B. (2015). The impact of Entrepreneurship Education and Entrepreneurial Attitudes and Intention: Hysteresis \& Persistence. Journal of Small Business Management, 53(1), 75-93.

[27] Kautonen, T., Van Gelderen, M. \& Tornikoski, E. T. (2013). Predicting entrepreneurial behaviour: a test of the theoryof planned behaviour. Applied Economics, 45(6), 607-707.

[28] Schwarz, E. J., Wdowiak M. A, Almer-Jarz D. A. \& Breitenecker R. J. (2009). The effects of attitudes and perceived environment conditions on students' entrepreneurial intent. Journal of Education and Training, 51 (4), 272-291.

[29] Franke, N. \& Luthje, C. (2004). Entrepreneurship intentions of business students: A benchmarking study', viewed October 23 2003, www2.wuwien.ac.at./entrepren/ modules? Updownload/store folder/Publikationen/ Nikolaus/Franke/entrepreneurialspirit.pdf.

[30] Lim, V. \& Teo, T. (2003). Sex, money and financial hardship: an empirical study of attitudes towards money among undergraduates in Singapore. Journal of Economic Psychology, 18, 369-86.

[31] Shane, S. Locke, E. A. \& Collins, C. J. (2003). Entrepreneurial motivation. Human Resources Management Review, 13(2), 257-79.

[32] Krueger, N. F., Reilly, M. D. \& Carsrud, A. L. (2000). Competing models of entrepreneurial intentions. Journal Business Venturing, 15, 411-432.

[33] Douglas, E. J. (1999). Entrepreneurship as a career choice: attitudes, entrepreneurial intentions, and utility maximisation. Frontiers of Entrepreneurship Research, Babson College, Wellesley, M. A.

[34] Autio, E, Keeley, R. H., Klofsten, M. (1997). Entrepreneurial intent among students: testing intent model in Asia, Scandinavia, and USA. Frontiers of Entrepreneurship Research, Babson College, Wellesley, MA.

[35] Denanyeh, R, Adjei, K. Effah Nuemekye, G. (2015). Factor that Impact on Entrepreneurial Intention of Tertiary Students in Ghana. International Journal of Business and Social Research, 5(3), 19-29.

[36] Fatoki, O. (2014). Parental and Gender Effects on the Entrepreneurial Intention of University Students in South Africa. Mediterranean Journal of Social Science. 5 (7), 157162.

[37] Romani, G., Atienza, M. \& Amoros, J. E. (2009). Financing entrepreneurial activity in Chile: scale and scope of public support programs. 11(1), 55-70. Routledge.

[38] Matlay, H. (2009). Entrepreneurship education in the U. K. Journal of Small Business and Enterprise Development, 16 (2), 355-368.

[39] Fehr, D. and Hishigsuren, G. (2006). Raising capital for microfinance: sources of funding and opportunities for equity financing. Journal of Development Entrepreneurship, vol. 11(2), 133-143.

[40] Reynolds, P., Bosma, N., Autio, E., Hunt, S., De Bono, N., Servais, I., Lo' pez-Garc1'a, P. \& Chin, N. (2005). Global Entrepreneurship Monitor: Data collection design and implementation 1998-2003. Small Business Economics, 24, 205-31. 
[41] Stevenson, L. \& A. Lundstro" m. (2005). Entrepreneurship policy for the future: Best practice components. In 'Keystones of entrepreneurship knowledge', ed. R. Van Der Horst, S. Kingkauanui, and S. Duffy, 177-94. Oxford: Blackwell Publishing.

[42] Storey J. (2005). 'Human Resource Management', 3rd edition, published by Thompson learning.

[43] Tan, J. \& Peng, M. (2003). Organizational slack and firm performance during economic transitions: Two studies from an emerging economy. Strategic Management Journal, 24 (13), 1249-1263.
[44] Rengiah, P. \& Sentosa, I. (2014). A Structural Equation Modelling of Entrepreneurial Education and Entrepreneurial Intentions among Malaysian University Students. International Journal of Business and Management Invention, 3 (11), 2-25.

[45] Hair, J. F., Black, W. C., Babin, B. J., Anderson, R. E. and Tatham, R. L. (2014), Multivariate Data Analysis, 7th edition, Pearson Prentice Hall, Upper Saddle River, New Jersey. 